\title{
Aedes aegypti Resistance to Temephos during 2001 in Several Municipalities in the States of Rio de Janeiro, Sergipe, and Alagoas, Brazil
}

\author{
Ima Aparecida Braga $/ * * *$, José Bento Pereira Lima/ ${ }^{*}$, Sidinei da Silva Soares***, \\ Denise Valle/*/+
}

Laboratório de Transmissores de Hematozoários, Departamento de Entomologia, Instituto Oswaldo Cruz-Fiocruz, Av. Brasil 4365, 21045-900 Rio de Janeiro, RJ, Brasil *Laboratório de Entomologia, Instituto de Biologia do Exército, Rio de Janeiro, RJ,

Brasil **Secretaria de Vigilância em Saúde, Brasília, DF, Brasil ***Fundação Nacional de Saúde, Rio de Janeiro, RJ, Brasil

For more than 30 years temephos, an organophosphate insecticide, has been the sole larvicide used in Brazil in the control of Aedes aegypti. Organophosphates were also used for adult control, being replaced by pyrethroids since 1999. In this same year, the Brazilian Health Foundation started the coordination of the Ae. aegypti Insecticide Resistance Monitoring Program. In the context of this program, our group was responsible for the detection of temephos resistance in a total of 12 municipalities in the states of Rio de Janeiro (RJ), Alagoas (AL), and Sergipe (SE) during 2001. In each municipality, a pool of mosquitoes collected from different districts was used, with the exception of Rio de Janeiro city, where eight districts have been separately evaluated. Exposure of larvae to the diagnostic dose of temephos revealed resistance in all localities examined, with mortality levels ranging from 4\% (Pilares district, Rio de Janeiro, RJ) to 61.9\% (Campos dos Goytacazes, RJ). Quantification of mortality showed resistance ratios from 6.1 (Aracaju, SE) to 16.8 (São Gonçalo, RJ and Penha district, Rio de Janeiro, RJ). The national dengue control program is presently using these data to subside insecticide resistance management.

Key words: Aedes aegypti - temephos - organophosphate - resistance - vector control - dengue

Dengue and yellow fever are viral diseases that have major consequences in public health. Dengue and dengue hemorrhagic fever are considered the most important and disseminated viral diseases transmitted by mosquitoes. Aedes aegypti plays a crucial role in transmission of these infections (PAHO 1995, Rodhain \& Rosen 1997, Nogueira et al. 1999).

Dengue is prevalent in urban areas and its occurrence is related to the geographic distribution of the vector (PAHO 1995). In Brazil, after almost 60 years without dengue register, an epidemic burst occurred in 1981, in Boa Vista, Roraima, when both serotypes DEN I and DEN IV circulated (Osanai et al. 1983), and was quickly contained. However, in 1986 a new dengue epidemic started, in the state of Rio de Janeiro (RJ), with the serotype DEN I (Schatzmayr et al. 1986) and was soon spread to the Northeast region of the country. Later, in 1990, DEN II was also detected in RJ (Nogueira et al. 1990, 1991, Miagostovich et al. 1993). More recently DEN III has been introduced in this state and, in the summer 2001/2002, the worst Brazilian dengue epidemics took place, starting at Rio de Janeiro

Financial support: Conselho Nacional de Desenvolvimento Científico e Tecnológico, Fundação de Amparo à Pesquisa do Estado do Rio de Janeiro, Fundação Oswaldo Cruz, and Fundação Nacional de Saúde

${ }^{+}$Corresponding author. Fax: +55-21-2580.6598. E-mail: dvalle@ioc.fiocruz.br

Received 23 June 2003

Accepted 22 January 2004 and soon reaching other 11 states (Nogueira et al. 2001, Barbosa-da-Silva et al. 2002).

Dengue control is primarily based on the use of chemical insecticides against Ae. aegypti. However, insecticide resistance in dengue vectors has been reported from other areas for a long time (Fox 1961, Brown 1986, WHO 1992). In this sense, the monitoring of Ae. aegypti insecticide resistance plays a key role in any vector control program (PAHO 1995, WHO 1997).

In Brazil, the organophosphate temephos is used in the control of Ae. aegypti larvae since 1967, being directly applied in the mosquito breeding sites (Ministério da Saúde 1968). After the 1986 dengue epidemics, organophosphates' use was intensified against larvae and adults, the latter being controlled through space sprays (to restrain dengue outbreaks) and residual perifocal applications. In 1999 the pyrethroid cypermethrin substituted organophosphates in the control of Ae. aegypti adults in the majority of the country, with exception of the state of São Paulo, where pyrethroids are used since 1989 (Macoris et al. 1999).

In 1999, the Brazilian Health Foundation (Funasa) started the coordination of an integrated program, designed to monitor the resistance of Ae. aegypti to insecticides used in its control (Funasa 1999). Firstly planned to evaluate resistance of larvae to temephos and of adults to malathion and fenitrothion, nowadays the monitoring program also includes pyrethroid bioassays. Since 1999, municipalities to be monitored are mainly chosen among those exhibiting high infestation levels or an elevated number of dengue cases. In both circumstances insecticide use and, consequently, insecticide selection pressure, are locally increased. In the first round of monitor- 
ing, in 1999, our group, responsible for the analysis of ten municipalities at both RJ and Espírito Santo states, detected alterations in temephos susceptibility in vector populations from all municipalities examined. Furthermore, resistance ratios three to 12 fold were found (Lima et al. 2003).

The present work deals with the second round of resistance monitoring, that took place in 2001. Bioassays against larvae derived from eggs collected at RJ, Sergipe (SE) and Alagoas (AL), designed to detect and quantify temephos resistance in these areas were carried out and will be discussed.

\section{MATERIALS AND METHODS}

Mosquitoes - In each municipality, several non-adjacent districts were chosen. Ovitraps were prepared according to Fay and Eliason (1966), using black plastic jars filled with hay infusion (Reiter et al. 1991, Braga et al. 2000). The number of ovitraps placed in the field was based on the number of buildings in each locality, as described previously (Lima et al. 2003). Field collection of eggs was done in September 2001 in municipalities from SE (Aracaju, Barra dos Coqueiros, and Itabaiana) and AL (Arapiraca and Maceió) and between January and July 2001 in the state of RJ (Campos dos Goytacazes, Duque de Caxias, Niterói, Nova Iguaçu, Rio de Janeiro, São Gonçalo, and São João de Meriti). For all the municipalities, eggs collected from the different districts were pooled (Fig. 1A). Exception was the municipality of Rio de Janeiro, RJ, where samples of each district (Bangu, Campo Grande, Jardim América, Penha, Pilares, Realengo, Rocha Miranda, and São Cristóvão) were evaluated separately (Fig. 1B). Except where indicated, 3rd instar Ae. aegypti $\mathrm{F} 1$ larvae were subjected to bioassays (Fig. 1A). The Rockefeller strain, reared continuously in the laboratory for many years, was used as the susceptible reference lineage.

Bioassays - Calibration of the temephos sample available to the monitoring program in 2001 (90\% technical grade, lot 024/00, obtained from Prodelyn Química, Sorocaba, SP) was performed with the Rockefeller strain. Bioassays were done with the recommended World Health Organization (WHO) protocol, described elsewhere (WHO 1981a, Lima et al. 2003), using $0.006 \mathrm{mg} / \mathrm{l}$ temephos as the diagnostic dose (twice the concentration of the dose that kills $99 \%$ of a susceptible strain $-\mathrm{LC}_{99}-$, as defined by WHO (1981a, b). Susceptibility of larvae from a total of 19 localities, comprising 8 districts from the municipality of Rio de Janeiro and 11 municipalities at RJ, SE, and AL was determined. In each population, three or four tests were performed, with a total of 160 larvae in treatment and 80 larvae in control per test. Rockefeller larvae were exposed to the temephos $\mathrm{LC}_{99}$ concomitantly with each assay, to serve as an internal control.

The resistance ratios $\left(\mathrm{RR}_{50}\right.$ and $\left.\mathrm{RR}_{90}\right)$ to temephos were estimated for 15 localities, through exposure of larvae to a range of 10 different insecticide concentrations (four replicas of 20 larvae per concentration and for the control samples, equivalent to 880 larvae per test). Data were compared to those obtained for the Rockefeller strain. Three to six tests were run with mosquitoes from each population.

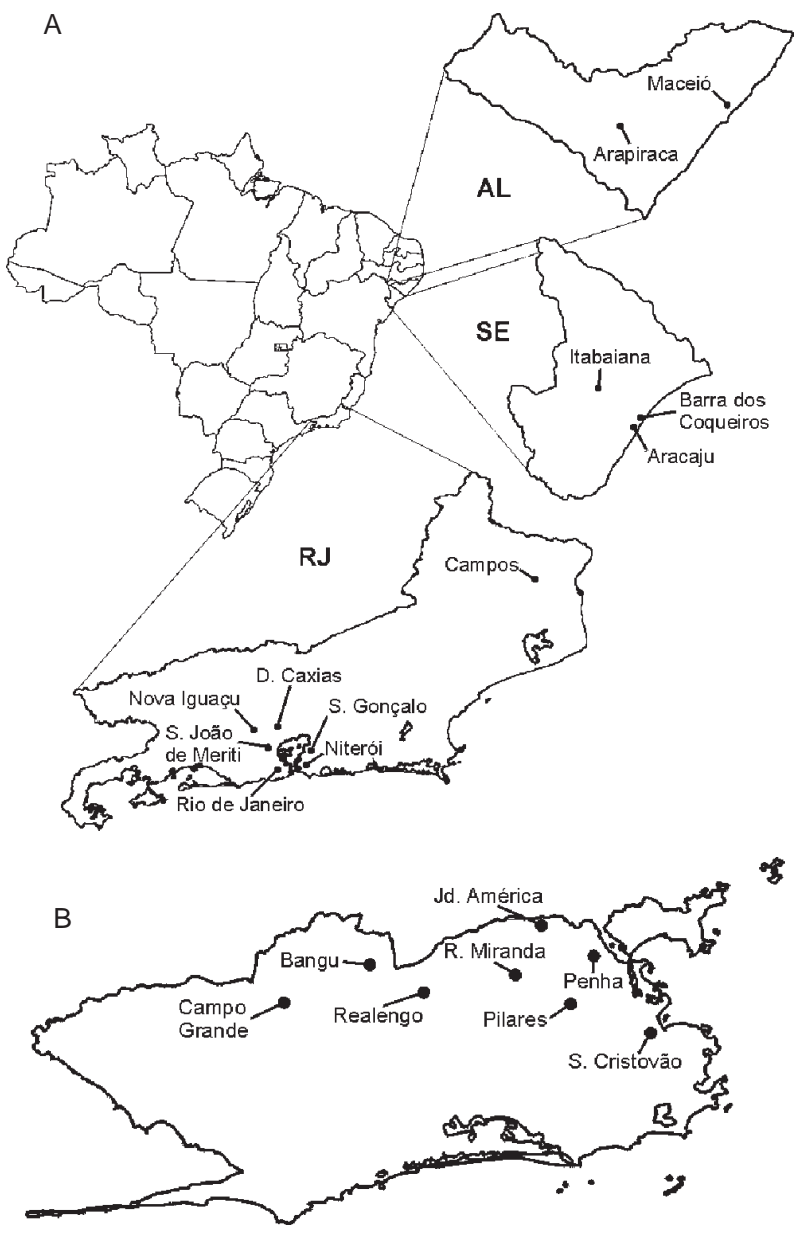

Fig. 1: location of areas from where mosquito eggs were collected. A: map of Brazil showing the states of Rio de Janeiro (RJ), Alagoas $(\mathrm{AL})$, and Sergipe (SE) and the location of the municipalities used in the study; B: map of Rio de Janeiro municipality, showing the location of the districts evaluated.

Evaluation criteria and statistical analysis - Bioassays performed with the diagnostic dose were evaluated according to criteria defined by Davidson and Zahar (1973): mortality higher than $98 \%$ and lower than $80 \%$ are indicative of susceptibility and resistance, respectively, and intermediate mortality levels suggest an incipient altered susceptible status.

Results from different dose-response assays of the same mosquito population were compared by ANOVA test. If significant differences were found $(\mathrm{P}<0.05)$, the discrepant assay was discarded and the other ones pooled. When no significant differences among the assays were detected $(\mathrm{P}>0.05)$, data were pooled and submitted to probit analysis, using the computer program GW-Basic 2.01 (1984) to define lethal concentrations (LC). Resistance ratios were calculated by comparison with results obtained with the reference strain, Rockefeller. The criteria proposed by Mazzarri and Georghiou (1995) was used to classify resistance ratios in high ( $>10$ fold), medium (between 5 and 10) and low $(<5)$. 


\section{RESULTS}

Larval bioassays with the diagnostic temephos dose - All the populations examined were classified as temephos resistant (Tables I, II). In the two states from the Northeast region examined, $\mathrm{SE}$ and $\mathrm{AL}$, Ae. aegypti mortality levels varied from $35.3 \%$ (Arapiraca, AL) to $7.1 \%$ (Itabaiana, SE). In RJ, these levels ranged from $61.9 \%$ (Campos dos Goytacazes) to $10.8 \%$ (São Gonçalo). In this latter municipality low mortality levels are particularly relevant if it is considered that bioassays have been performed with F2 (instead of F1) larvae, grown in the laboratory, in the absence of any insecticide selection pressure.

In the eight districts of Rio de Janeiro city evaluated, the higher mortality was obtained in Rocha Miranda district $(42.9 \%)$. Three districts (Jardim América, Penha, and Pilares), exhibited mean mortality below $10 \%$, the lower level being observed at Pilares (4\%) (Table II).

Quantification of temephos resistance - Mosquitoes from the Northeast region of Brazil submitted to the doseresponse bioassays presented $\mathrm{RR}_{90}$ from 6.1 (Aracaju,

\section{TABLE I}

Bioassays with the temephos diagnostic dose of Aedes aegypti larvae from different municipalities in the states of Alagoas (AL), Sergipe (SE), and Rio de Janeiro (RJ) during 2001

\begin{tabular}{|c|c|c|}
\hline State & Municipality & $\%$ mortality \\
\hline & Rockefeller (lab) & 100 \\
\hline \multirow[t]{2}{*}{ AL } & Maceió & $20.0 \pm 12.8$ \\
\hline & Arapiraca & $35.3 \pm 23.7$ \\
\hline \multirow[t]{3}{*}{ SE } & Aracaju & $27.5 \pm 2.7$ \\
\hline & Barra dos Coqueiros & $26.7 \pm 19.6$ \\
\hline & Itabaiana & $7.1 \pm 2.4$ \\
\hline \multirow[t]{6}{*}{ RJ } & Campos dos Goytacazes & $61.9 \pm 17.6$ \\
\hline & Duque de Caxias ${ }^{a}$ & $53.1 \pm 3.5$ \\
\hline & Niterói & $44.0 \pm 14.4$ \\
\hline & Nova Iguaçu & $24.6 \pm 9.9$ \\
\hline & São Gonçalo ${ }^{a}$ & $10.8 \pm 5.2$ \\
\hline & São João de Meriti $a$ & $33.1 \pm 2.7$ \\
\hline
\end{tabular}

Data refer to mean \pm standard deviation; $a$ : bioassays performed with 3rd instar larvae of the F2 generation. In the other cases, F1 larvae were used.
TABLE II

Bioassays with the temephos diagnostic dose of Aedes aegypti larvae from different districts of the municipality of Rio de Janeiro during 2001

\begin{tabular}{lc}
\hline District & \% mortality \\
\hline Rockefeller (lab) & 100 \\
Bangu & $12.5 \pm 7.6$ \\
Campo Grande & $11.9 \pm 3.5$ \\
Jardim América & $9.2 \pm 0.6$ \\
Penha & $6.0 \pm 4.7$ \\
Pilares & $4.0 \pm 3.5$ \\
Realengo & $10.4 \pm 6.6$ \\
Rocha Miranda & $42.9 \pm 33.3$ \\
São Cristóvão & $30.2 \pm 21.9$ \\
\hline
\end{tabular}

Data refer to mean \pm standard deviation

SE) to 11.2 (Barra dos Coqueiros, SE) (Table III). Although these tests have been performed with the F2 generation, in all cases, populations' heterogeneity was still higher than that of the Rockefeller strain, as judged by the slope values obtained.

In the state of RJ (excluding Rio de Janeiro municipality), the lower and higher $\mathrm{RR}_{90}$ were, respectively, 7.5 in São João de Meriti and 16.8 in São Gonçalo municipalities (Table III). Again in this case slope values were lower when compared to the reference strain, indicating higher heterogeneity, as expected.

In the municipality of Rio de Janeiro, where the analysis was done in several districts separately, $\mathrm{RR}_{90}$ values ranged from 7.4 (Rocha Miranda) to 16.8 (Penha). Vector populations from the different districts of Rio de Janeiro city tended to be less heteregeneous than those from the municipalities whose districts were analyzed in pool (compare slope values shown in Tables III and IV).

\section{DISCUSSION}

The Brazilian Ae. aegypti resistance monitoring program detected temephos resistance in Ae. aegypti populations from several localities in the country in 1999 (Funasa 2000, Lima et al. 2003). The present work deals with results obtained in the monitoring performed during 2001.

TABLE III

Lethal concentrations $(\mathrm{mg} / \mathrm{l})$ and resistance ratio to temephos of Aedes aegypti larvae from different municipalities of the states of Alagoas (AL), Sergipe (SE), and Rio de Janeiro (RJ) during 2001

\begin{tabular}{|c|c|c|c|c|c|c|c|}
\hline State & Municipality & $\mathrm{F}$ & $\mathrm{LC}_{50}$ & $\mathrm{LC}_{90}$ & Slope & $\mathrm{RR}_{50}$ & $\mathrm{RR}_{90}$ \\
\hline & Rockefeller (lab) & & 0.0011 & 0.0019 & 5.6 & 1 & 1 \\
\hline AL & Maceió & $\mathrm{F} 2$ & 0.0071 & 0.0163 & 3.6 & 8.6 & 9.4 \\
\hline \multirow[t]{2}{*}{$\mathrm{SE}$} & Aracaju & $\mathrm{F} 2$ & 0.0048 & 0.0106 & 3.7 & 5.8 & 6.1 \\
\hline & Barra dos Coqueiros & $\mathrm{F} 2$ & 0.0078 & 0.0193 & 3.3 & 9.4 & 11.2 \\
\hline \multirow[t]{6}{*}{$\mathrm{RJ}$} & Campos dos Goytacazes & $\mathrm{F} 2$ & 0.0070 & 0.0135 & 4.5 & 8.5 & 7.8 \\
\hline & Duque de Caxias & F3 & 0.0062 & 0.0148 & 3.4 & 7.5 & 8.5 \\
\hline & Niterói & $\mathrm{F} 2$ & 0.0112 & 0.0250 & 3.7 & 13.5 & 14.4 \\
\hline & Nova Iguaçu & $\mathrm{F} 2 / \mathrm{F} 3$ & 0.0066 & 0.0142 & 3.9 & 8.0 & 8.2 \\
\hline & São Gonçalo & $\mathrm{F} 2$ & 0.0129 & 0.0290 & 3.6 & 15.5 & 16.8 \\
\hline & São João de Meriti & $\mathrm{F} 2$ & 0.0048 & 0.0130 & 2.9 & 5.8 & 7.5 \\
\hline
\end{tabular}

F indicates the generation used for the tests. 
TABLE IV

Lethal concentrations (mg/l) and resistance ratio to temephos of Aedes aegypti larvae from different districts of Rio de Janeiro municipality during 2001

\begin{tabular}{llccccc}
\hline District & $\mathrm{F}$ & $\mathrm{LC}_{50}$ & $\mathrm{LC}_{90}$ & Slope & $\mathrm{RR}_{50}$ & $\mathrm{RR}_{90}$ \\
\hline Rockefeller (lab) & & 0.0011 & 0.0019 & 5.6 & 1 & 1 \\
Jardim América & $\mathrm{F} 1 / \mathrm{F} 2$ & 0.0152 & 0.0273 & 5.0 & 3.5 & 18.3 \\
Penha & $\mathrm{F} 2$ & 0.0125 & 0.0290 & 4.7 & 15.1 & 16.8 \\
Pilares & $\mathrm{F} 1 / \mathrm{F} 2$ & 0.0124 & 0.0231 & 4.4 & 8.7 & 13.4 \\
Realengo & $\mathrm{F} 2 / \mathrm{F} 3$ & 0.0072 & 0.0141 & 3.0 & 5.8 & 7.4 \\
Rocha Miranda & $\mathrm{F} 2$ & 0.0048 & 0.0129 & 4.4 & 9.9 & 9.3 \\
São Cristóvão & $\mathrm{F} 2$ & 0.0083 & 0.0161 & & & \\
\hline
\end{tabular}

$\mathrm{F}$ indicates the generation used for the tests.

Diagnostic dose bioassays revealed that all Ae. aegypti populations evaluated are resistant to temephos (Tables I, II). In the state of RJ, the comparison with 1999 data (Lima et al. 2003) indicated mortality rates equivalent to the present ones in Campos dos Goytacazes (74\% in 1999 and 61.9\% in 2001) and Niterói (34.6\% in 1999 and $44 \%$ in 2001). In 2001, mortality levels increased in Duque de Caxias (34.8\% in 1999 and $53.1 \%$ in 2001) and were significantly lower in the remaining municipalities ( $t$ test, $\mathrm{p}<0.05)$.

According to Mazzarri and Georghiou (1995) classification (see Materials and Methods), temephos resistance in the municipalities of RJ (Table III), revealed high RR in two of them (Niterói and São Gonçalo), while the others presented mean RR. During the 1999 monitoring, the $\mathrm{RR}_{90}$ of three municipalities of RJ (Duque de Caxias, São Gonçalo, and São João de Meriti) was calculated (Lima et al. 2003). Comparison with values shown here indicate that only mosquitoes from São João de Meriti changed their RR, exhibiting low temephos RR in $1999\left(R_{90}=3.6\right)$ and mean $R R$ in $2001\left(R_{90}=7.5\right)$. Duque de Caxias and São Gonçalo mosquitoes presented, respectively, mean and high RR in both evaluations.

In 1999, mosquitoes from the city of Rio de Janeiro were already resistant to temephos (Lima et al. 2003). During 2001, populations of eight districts, spread over the city (Fig. 1B), were tested separately, confirming resistance in this municipality. As stated previously by Rawlins (1998), a good correlation was found between RR values and survival after treatment with the diagnostic dose: mosquitoes derived from all three districts that exhibited mortality below $10 \%$ with the temephos diagnostic dose (Table II) presented high RR levels (Table IV).

Bioassays with the temephos diagnostic dose revealed resistance in all the AL and SE municipalities evaluated during the 2001 monitoring. Data from 1999 already indicated resistance in four out of five populations analyzed (Macoris 2002). Resistance ratios were evaluated for three AL and SE municipalities (Table III), indicating high levels only in Barra dos Coqueiros (SE), the other two municipalities, Maceió and Aracaju, exhibiting mean RR. Our results are consistent with those found for samples collected during 1999, with the exception of Barra dos Coqueiros, that was previously classified as a low resistant population $\left(\mathrm{RR}_{95}=3.2\right)$ (Macoris 2002).
During the 1999 monitoring, the use of temephos at $0.012 \mathrm{mg} / \mathrm{l}$ as the diagnostic dose, as indicated by WHO, was recommended (WHO 1992, Funasa 1999). At that time, calibrations performed by our group confirmed the concentration of $0.006 \mathrm{mg} / \mathrm{l}$ as the temephos $\mathrm{LC}_{99}$ (Lima et al. 2003). However, during the 2001 assays, calibrations with the temephos sample available at that time led to the use of $0.006 \mathrm{mg} / \mathrm{l}$ as the diagnostic dose. Variations in the absolute values of the diagnostic dose have been noted among the laboratories participating in the Brazilian Ae. aegypti resistance monitoring program and, sometimes, even among different tests performed by the same laboratory in different years. For instance, the laboratory located in São Paulo used $0.008 \mathrm{mg} / \mathrm{l}$ as the diagnostic dose during the 1999 monitoring (Macoris et al. 2003) and 0.012 $\mathrm{mg} / \mathrm{l}$ for the 2002/2003 assays (Secretaria Estadual de Saúde, Superintendência de Controle de Endemias, Sucen, internal report 2003).

Presently, the Ae. aegypti resistance monitoring program officially opted to use twice the $\mathrm{LC}_{99}$ temephos value defined yearly by each laboratory as the diagnostic dose. Parallel exposure of the susceptible reference strain (Rockefeller) to the $\mathrm{LC}_{99}$ is also included, as an internal control of all the assays. As an additional control, mosquito samples from some localities are exchanged among laboratories and submitted to double blind tests. Furthermore, local evaluation of the purity level and stability of the temephos samples that are available to the laboratories each year are planned.

The above results and those from the other laboratories participating in the monitoring program, together with field evaluations assisted Funasa decision to replace temephos with Bacillus thuringiensis spp. israelensis (Bti) in some localities. Bti action involves the activation of pro-toxins inside the mosquito larva gut (WHO 1999), a mechanism totally distinct from the organophosphates, which act on the central nervous system of the insect. The purpose of this substitution was to stop the temephos selection pressure operating since many years (Ministério da Saúde 1968, Funasa 2001). The Metropolitan region of the state of Rio de Janeiro was the first example, since several temephos field evaluations indicated loss of effectiveness (Funasa 1999), corroborating laboratory resistance detections.

In conclusion, we found resistance to temephos in $A e$. 
aegypti populations in the 12 municipalities evaluated, at RJ, AL, and SE. Although temephos has been substituted for the biolarvicide Bti at the state of RJ during 2001, the evaluations shown here, performed with samples collected in this same year, do not reflect these insecticide changes yet. Data from the Ae. aegypti resistance monitoring program are being continuously evaluated, together with entomological and epidemiological surveillance and with field evaluation of insecticides, in order to help the definition of local control measures. Additionally, evaluation of biochemical mechanisms involved in resistance of the $A e$. aegypti populations here presented is being performed.

\section{ACKNOWLEDGEMENTS}

To Rita de Cássia Galhardo de Melo (Funasa/RJ), Rita Selene Bezerra Almeida (Secretaria Estadual de Saúde/SE), Cleide Moreira (Secretaria Estadual de Saúde/AL) and the Entomology personnel from the Secretarias Estaduais of Rio de Janeiro, Sergipe, and Alagoas for field collection of eggs. To Maria de Lourdes Macoris (Sucen/SP) for discussions regarding the resistance monitoring performed during 1999 in the states of SE and AL.

\section{REFERENCES}

Barbosa-da-Silva Jr J, Siqueira Jr JB, Coelho GE, Vilarinhos PT, Pimenta Jr FG 2002. Dengue in Brazil: current situation and prevention and control activities. Epidemiol Bull 23:3-6.

Braga IA, Gomes AC, Nelson M, Mello RCG, Bergamaschi DP, Souza JMP 2000. Comparative study between larval surveys and ovitraps to monitor populations of Aedes aegypti. Rev Soc Bras Med Trop 33: 347-353.

Brown AW 1986. Insecticide resistance in mosquitoes: a pragmatic review. J Am Mosq Control Assoc 2: 123-140.

Davidson G, Zahar AR 1973. The practical implications of resistance of malaria vectors to insecticides. Bull WHO 49: 475-483.

Fay RW, Eliason DA 1966. A preferred oviposition site as a surveillance method for Aedes aegypti. Mosq News 26: 531-535.

Fox I 1961. Resistance of Aedes aegypti to certain chlorinated hydrocarbon and organophosphorus insecticides in Puerto Rico. Bull WHO 24: 489-494.

Funasa 1999. Reunião técnica para discutir status de resistência de Aedes aegypti e definir estratégias a serem implantadas para monitoramento da resistência no Brasil. Fundação Nacional de Saúde, Ministério da Saúde, Brasília.

Funasa 2000. Relatório da reunião de avaliação do monitoramento da resistência das populações de Aedes aegypti do país. Fundação Nacional de Saúde, Ministério da Saúde, Brasília.

Funasa 2001. Dengue. Instruções para Pessoal de Combate ao Vetor. Manual de Normas Técnicas, 3a. ed., Fundação Nacional de Saúde, Ministério da Saúde, Brasília.

Lima JBP, Pereira da Cunha M, Silva-Jr RCS, Galardo AKR, Soares SS, Braga IA, Ramos RP, Valle D 2003. Resistance of Aedes aegypti to organophosphates in several municipalities in the state of Rio de Janeiro and Espírito Santo, Brazil. Am J Trop Med Hyg 68: 329-333.

Macoris MLG 2002. Avaliação do Nível de Susceptibilidade de Linhagens de Aedes aegypti (Diptera:Culicidae) aos Inseticidas Utilizados para seu Controle, MSc Thesis, Faculdade de Medicina de Botucatu, Universidade Estadual Paulista, Botucatu, SP, Brasil.

Macoris MLG, Andrighetti MT, Takaku L, Glasser CM,
Garbeloto VC, Bracco JE 2003. Resistance of Aedes aegypti from the state of Sao Paulo, Brazil, to organophosphates insecticides. Mem Inst Oswaldo Cruz 98: 703-708.

Macoris MLG, Andrighetti MTM, Takaku L, Glasser CM, Garbeloto VC, Cirino VCB 1999. Alteration in susceptibility response of Aedes aegypti to organophosphates in cities in the state of S. Paulo, Brazil. Rev Saúde Púb 33: 521-522.

Mazzari MB, Georghiou GP 1995. Characterization of resistance to organophosphate, carbamate, and pyrethroid insecticides in field populations of Aedes aegypti from Venezuela. J Am Mosq Cont Assoc 11: 315-322.

Miagostovich MP, Nogueira RMR, Cavalcanti SMB, Marzochi KBF, Schatzmayr HG 1993. Dengue epidemic in the state of Rio de Janeiro, Brazil: virological and epidemiological aspects. Rev Inst Med Trop São Paulo 35: 149-154.

Ministério da Saúde 1968. Endemias Rurais - Métodos de trabalho adotados pelo DNERu, Departamento Nacional de Endemias Rurais.

Nogueira RM, Miagostovich MP, de-Filippis AM, Pereira MA, Schatzmayr HG 2001. Dengue virus type 3 in Rio de Janeiro, Brazil. Mem Inst Oswaldo Cruz 96: 925-926.

Nogueira RMR, Miagostovich MP, Lampe E, Schatzmayr HG 1990. Isolation of dengue virus type 2 in Rio de Janeiro. Mem Inst Oswaldo Cruz 85: 253.

Nogueira RMR, Miagostovich MP, Schatzmayr HG, Santos FB, Araujo ESM, Filippis AMB, Souza RV, Zagne SMO, Nicolai C, Baran M, Teixeira-Filho G 1999. Dengue in the State of Rio de Janeiro, Brazil 1986-1998. Mem Inst Oswaldo Cruz 94: 297-304.

Nogueira RM, Zagner SM, Martins IS, Lampe E, Miagostovich MP, Schatzmayr HG 1991. Dengue haemorrhagic fever/ dengue shock syndrome (DHF/DSS) caused by serotype 2 in Brazil. Mem Inst Oswaldo Cruz 86: 269.

Osanai CH, Travassos-da-Rosa APA, Amaral S, Passos ACD, Tauil PL 1983. Surto de dengue em Boa Vista, Roraima. Rev Inst Med Trop São Paulo 1: 53-54.

PAHO 1995. Dengue y Dengue Hemorrágico en las Américas - Guias para su Prevencion y Control, Pan American Health Organization, Pub Cient 548, Washington.

Rawlins SC 1998. Spatial distribution of insecticide resistance in Caribbean populations of Aedes aegypti and its significance. Rev Panam Salud Publica 4: 243-251.

Reiter P, Amador MA, Colon N 1991. Enhancement of the CDC ovitrap with hay infusions for daily monitoring of Aedes aegypti populations. J Am Mosq Cont Assoc 7: 5254.

Rodhain F, Rosen L 1997. Mosquito vectors and dengue virusvector relationships. In DJ Gubler, G Kuno (eds), Dengue and Dengue Hemorrhagic Fever, CAB International, New York, p. 45-60.

Schatzmayr HG, Nogueira RMR, Rosa APAT 1986. An outbreak of dengue virus at Rio de Janeiro. Mem Inst Oswaldo Cruz 95: 179-181.

WHO 1981a. Instructions for Determining the Susceptibility or Resistance of Mosquito Larvae to Insecticides, WHO/VBC/ 81.807, World Health Organization, Geneva.

WHO 1981b. Criteria and Meaning of Tests for Determining the Susceptibility or Resistance of Insects to Insecticides, WHO/VBC 81.6, World Health Organization, Geneva.

WHO 1992. Vector Resistance to Pesticides, Fifteenth report of the WHO expert committee on Vector Biology and Control, World Health Organization, Geneva.

WHO 1997. Dengue Haemorragic Fever: Diagnostic, Treatment, Prevention and Control, 2 nd ed., World Health Organization, Geneva.

WHO 1999. Environmental Health Criteria 217. Bacillus thuringiensis. World Health Organization, Geneva. 